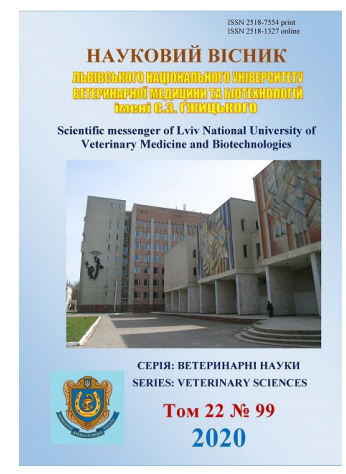

Науковий вісник Дьвівського націонадьного університету ветеринарної медицини та біотехнодогій імені С.3. Гжицького. Серія: Ветеринарні науки

\author{
Scientific Messenger of Lviv National University \\ of Veterinary Medicine and Biotechnologies. \\ Series: Veterinary sciences
}

UDC $436.52 .58+619$

\title{
Possibility to use erythrocyte antigens and feather coloration genes to determine resistance to non-plastic diseases
}

\author{
L. P. Livoschenko, Y. M. Livoschenko
}

Sumy National Agrarian University, Sumy, Ukraine

Article info

Received 14.09.2020

Received in revised form 12.10 .2020

Accepted 13.10.2020

Sumy National Agrarian University, G. Kondrat'eva, 160 , Sumy, 40000, Ukraine. Tel.: +38-050-102-93-78 E-mail:evglivoshhenko@gmail.com
Livoschenko, L. P., \& Livoschenko, Y. M. (2020). Possibility to use erythrocyte antigens and feather coloration genes to determine resistance to non-plastic diseases. Scientific Messenger of Lviv National University of Veterinary Medicine and Biotechnologies. Series: Veterinary sciences, 22(99), 143-147. doi: 10.32718/nvlvet9921

Non-plastic diseases are a problem in both medical and veterinary practice. These include lymphoid leukemia (LL) and Marek's disease (CM). It should be noted that HM causes losses to poultry three times higher than LL. CM is a highly contagious viral neoplastic disease of chickens. It is known that the degree of resistance of different breeds and lines of chickens to Marek's disease (CM) and lymphoid leukemia (LL) is not the same. To date, little attention has been paid to the role of erythrocyte antigenic factors in the bird's response to morbidity. There is a relationship between the incidence among vaccinated birds and the natural susceptibility to HM birds of certain breeds and lines. The effect of protective reactions in chickens associated with erythrocyte antigenic factors in poultry selected for resistance to non-plastic diseases is still unclear. The objects of the study were chickens and 11-day-old embryos of poultry from one of the farms of Ukraine. The studies were performed on Rhode Island, Leghorn D4 and P-37 chickens. Standard strains of Rouse's sarcoma virus (HRV) were used in the study. Embryos of 11 days of incubation were infected with Rouse virus on the chorio-allantoic membrane (CAM). The results of the studies proved that the resistance to HRV had a significantly opposite correlation only with the presence of $B_{16}$ antigen and the absence of $X_{31}$. In chickens of the P-37 line we noted a probable difference in the number of birds of different genetic groups at loci B18 and E 8. Among birds of this line of genotypes rs and ss no individuals with locus $E_{8}$ were found, while among chickens with genotype rr rarely found a bird with a locus $B_{18}$. In hens of line D-4 with genotype $r r$, the frequency of the $A_{12}$ locus was set more often than in genotypes $r s$ and ss. As for the frequency of the $B_{33}$ locus, the opposite pattern was observed. Tumor regression was probably more common in birds with antigenic factor $B_{1}$ and in the absence of $B_{33}$. Hypersensitivity to non-plastic diseases of chickens carrying $B_{2}, B_{21}, B_{29}, X_{50}$ antigens has been established. The bird, more resistant to neoplasms, had an increased number of antigens $B_{3}, B_{18}, C_{26}$. and research in this direction continues. It is assumed that the plumage color gene (s), if present in homozygous form, is an inhibitor of sensitivity. The experiments used embryos and chickens with different plumage color: red, black, white with a yellow tinge, pure white. Their ratio is approximately 2:1:1 or 3 parts "colored" and 1 part white. It was found that among the "colored" embryos were more stable than sensitive. In fact, the resulting cleavage was close to expected.

Key words: chickens, embryos, leukemia-sarcoma complex viruses, Raus sarcoma virus, Marek's disease, erythrocyte antigens, plumage gene.

\section{Можливість використання антигенів еритроцитів i генів забарвлення оперення птиці для визначення стійкість до непластичних захворювань}

\author{
Л. П. Лівощенко, Є. М. Лівощенко \\ Сумський національний аграрний університет, м. Суми, Украӥна
}


Непластичні захворювання с проблемою як в медичній, так і в ветеринарній практиці. До них відносяться лімфоїдний лейкоз (ЛЛ) і хвороба Марека (ХМ). Треба відмітити, щзо ХМ завдає птахівнищтву збитків в тричі вищих, ніж ЛЛ. ХМ високо контагіозне вірусне неопластичне захворювання курей. Відомо, щуо ступінь стійкості різних порід і ліній курей до хвороби Марека (ХМ) і лімфоїному лейкозу (ЛЛ) неоднакова. До теперішнього часу мало уваги приділялося ролі антигенним факторам еритроцитів в реакиії організму птиці на захворюваність. С залежність між захворюваністю серед вакцинованої птичі $і$ природною чутливістю до ХМ птиці певних порід і ліній. Вплив захисних реакцій у курей, щуо пов 'язаний з антигенними фактори еритроцитів у птиці, селекціонованих за стійкістю до непластичних захворювань досі залишаються нез'ясованими. Об'єктами дослідження були кури і 11-денні зародки птиці одного із господарств України. Дослідження проводили на курях породи род-айленд, леггорн лінії Д4 та полтавській глинястій породи Пзз. В роботі були використані стандартні итами вірусу саркоми Рауса (ВСР). Ембріони 11-денної інкубаиії заражали вірусом Рауса на хоріо-аллантоїсну оболонку (ХАО). Результати досліджень довели, що стійкість до ВСР мала вірогідно протилежну кореляцію тільки з наявністю антигену $B_{16}$ і відсутністю $X_{31}$. курей лінії П-37 нами відзначена вірогідна різниця в кількості птиці різних генетичних груп по локусам $B_{18}$ i E 8. Серед птиці иієї лінії генотипів rs $i$ ss не встановлено особин, щчо мають локус $E_{8}$, в той час як серед курей з генотипом гг вірогідно рідше виявляли птицю з локусом В 8. У курей лінії Д-4 з генотипом гг частота локусу $A_{12}$ установлювали частіше, ніж у генотипів rs i ss. Що стосується частоти локусу Взз, то спостерігали зворотну закономірність. Регресія пухлин вірогідно частіше відбувалася у птиці, щзо мала антигенний фактор В $і$ і при відсутності $B_{33 .}$ Встановлена підвищена чутливість до непластичних захворювань курей носіїв антигенів $B_{2}$, В21, В29, $X_{50 .}$ Більи стійка до неоплазмам птиця мала підвищену кількість антигенів $B_{3}, B_{18}, C_{26}$. Дослідження в цьому напрямку тривають. Припускається, щзо ген забарвлення оперення (i), якщо він є в гомозиготній формі, являється інгібітором чутливості. В дослідах використовувалися ембріони і курчата з різним забарвленням оперення: червоні, чорні, білі з жовтим відтінком, чисто білі. Співвідношення їх приблизно 2:1:1 або 3 частини “забарвлених” і 1 частина білих. Установлено, щуо серед “забарвлених” ембріонів стійких було більше, ніж чутливі. Фактично отримане розщеплення виявилося близьким до очікуваного.

Ключові слова: курчата, ембріони, віруси лейкозо-саркомного комплексу, вірус саркоми Рауса, хвороба Марека, антигени еритрочитів, ген забарвлення оперення.

\section{Вступ}

Сучасне птахівництво - одна з рентабельних галузей тваринництва. Яйце і м'ясо птиці є дієтичним продуктом для харчування людини (Tsang et al., 1999; Plachý et al., 2017; Vahrusheva, 2020). На жаль, стримують подальший розвиток промислового птахівництва різні захворювання птиці заразної етіології (Plotnikov et al., 2013). До таких відносяться неопластичні хвороби птиці, що реєструються серед усіх порід і ліній курей. За даними ряду авторів економічні збитки, які завдає ХM, в три рази перевищує збитки, що наноситься хворобами лейкозо-саркомної групи (Payne \& Nair, 2012; Bhutia \& Damodar, 2017). Птиця, що уражена онкарновірусами, втрачає вагу, уповільнює ріст (Rubin, 2011). Загибель від ХМ і ЛЛ і вимушений забій завдає величезний економічний збиток, який може коливатися від $10 \%$ до $60 \%$, залежно від форми прояву хвороби. Крім того, необхідно враховувати і витрати на ветеринарно-санітарні заходи, по ліквідації захворювання та збитки за рахунок зниження продуктивності (Payne \& Venugopal, 2000; Soujanya et al., 2019; Vahrusheva, 2020).

Відомо, що ступінь стійкості різних порід і ліній курей до хвороби Марека (XМ) і лімфоїдному лейкозу (ЛЛ) неоднакова. До теперішнього часу мало уваги приділялося ролі антигенним факторам еритроцитів в реакції організму птиці на захворюваність.

Є залежність між захворюваністю серед вакцинованої птиці і природною чутливістю до ХМ птиці певних порід і ліній. Вплив захисних реакцій у курей, що пов'язаний з антигенними фактори еритроцитів у птиці, селекціонованих за стійкістю до непластичних захворювань досі залишаються нез'ясованими (Раупе \& Venugopal, 2000; Plachý et al., 2017).

Мета роботи: дослідити вплив антигенних факторів еритроцитів і генів забарвлення оперення птиці на стійкість до неопластичних хвороб в стаді курей порід леггорн і полтавська глиняста, селекціонованих на підвищену стійкість до онкорнавірусів.

\section{Матеріал і методи досліджень}

Дослідження проводили на курях породи родайленд, леггорн лінії Д4 та полтавській глинястій породи $\Pi_{37}$.

В роботі були використані стандартні штами вірусу саркоми Рауса (ВСР), що належать до різних підгруп вірусів лейкозо-саркомной групи (Бріан, RAV-2), вірус еритроїдного лейкозу штам R, вірус хвороби Марека (штам 3К). Матеріалом для зараження служив вірус в розведенні $10^{-1,5}, 10^{-2,5}, 10^{-4,5}, 10^{-5,5}$ (за вихідний матеріал брали пухлинну тканину. $30 \%$ суспензія відповідала розведення $10^{-0,5}$ ). Кожним розведенням вірусу в об'ємі 0.1 мл заражали в перетинку крила чотирьох курчат. Перший облік реакції проводили на 10 день після інфікування, а наступні - через 2 дні протягом двох тижнів. За позитивну реакцію на введення вірусу вважали утворення пухлини на місці ін'єкції пухлинного матеріалу.

Ембріони 11-денної інкубації заражали вірусом Рауса на хоріо-аллантоїсну оболонку. 3 цією метою робили штучну повітряну камеру 3 боку поверхні яйця. Ця операція проводилася наступним чином. Під контролем овоскопа визначали місце розташування природної пуги і робили прокол шкаралупи на середині повітряної камери. Далі на бічній поверхні пропилювали шкаралупу, розривали підшкарлупну оболонку і під контролем овоскопа з допомогою пастерівської піпетки і надітої на неї гумової трубочки відсмоктували повітря. Хоріо-аллантоисна оболонка відділася від підшкарлупної, утворюючи повітряну камеру. Ембріони клали на спеціальні лоточки в горизонтальному положенні штучно утвореним отвором вгору і поміщали в термостат на 1,5-2 години для фіксації пуги Потім на оболонку наносили вірус в об'ємі 0.1 мл. 


\section{Результати та їх обговорення}

Згідно 3 літературними даними встановлений зв'язок між наявністю певних еритроцитарних антигенів та захворюваністю птиці на неопластичні хвороби. Дослідження проводилися з сироватками, що не пройшли міжнародної атестації на здатність диференціювати певні локуси. Це ускладнювало виявлення серед них тих сироваток, які, згідно з літературними даними, виявляють серед птиці стійкі особини до неоплазм. Виходячи з цього, нами проведено дослідження багатьох антигенних факторів еритроцитів у птиці, що різнилися по чутливості до ВСР, здатності до регресії пухлин і стійкості до хвороби Марека.

На рисунку 1 представлені дані про стійкості до ВСР птиці з різною частотою певних антигенних факторів еритроцитів.

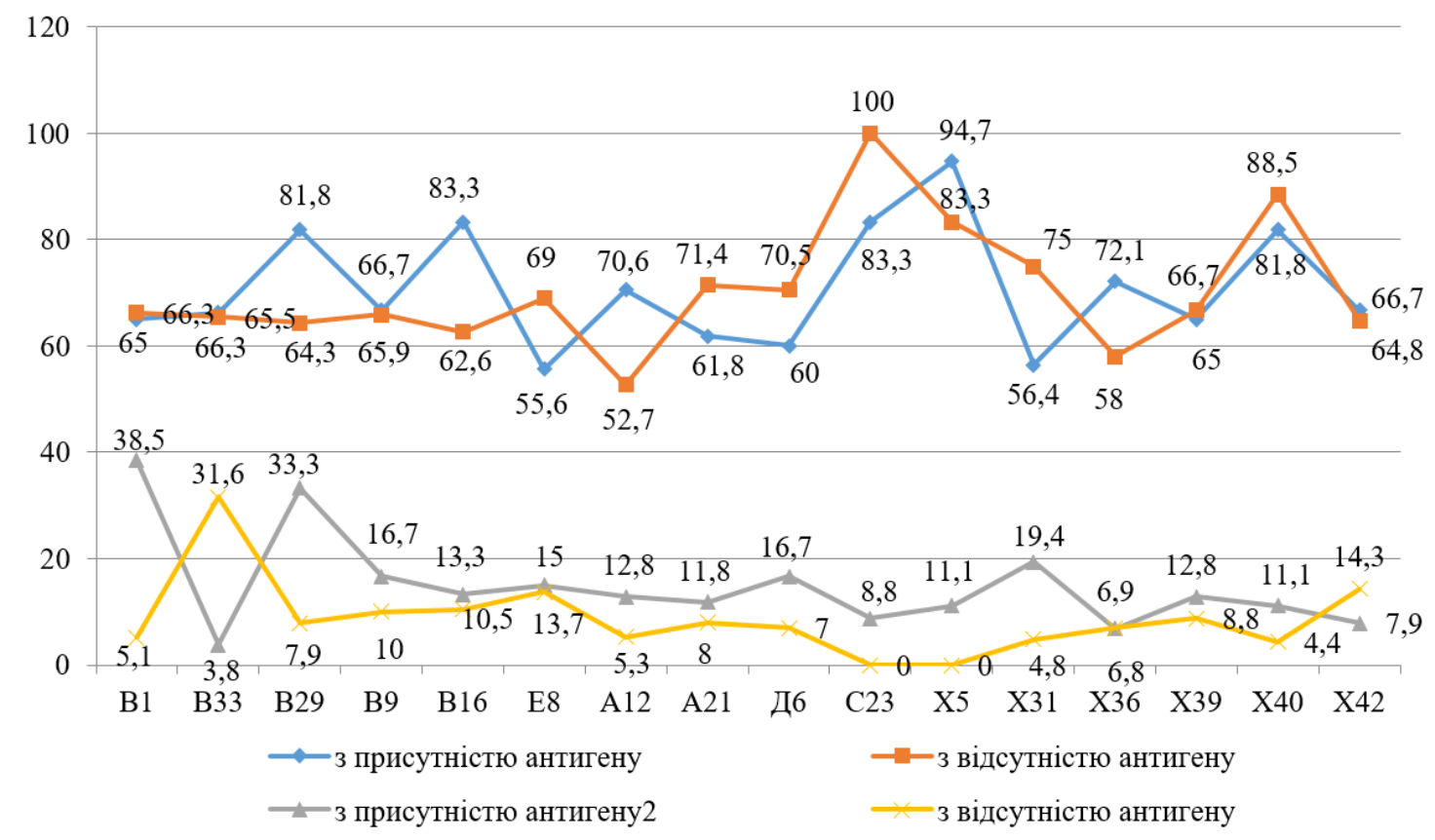

Рис. 1. Вплив еритроцитарних антигенів на стійкість птиці на стійкість до ВСР

Згідно $з$ даними рисунка 1 стійкість до ВСР мала вірогідно протилежну кореляцію тільки 3 наявністю антигену $\mathrm{B}_{16}$ і відсутністю $\mathrm{X}_{31}$. Повторні дослідження, проведені на птиці лінії Д-4, не підтвердили такого зв'язку з зазначеними антигенами.
Нами досліджувався зв'язок між наявністю певних еритроцитарних антигенів та стійкістю до ВСР птиці різних генотипів (рис. 2).

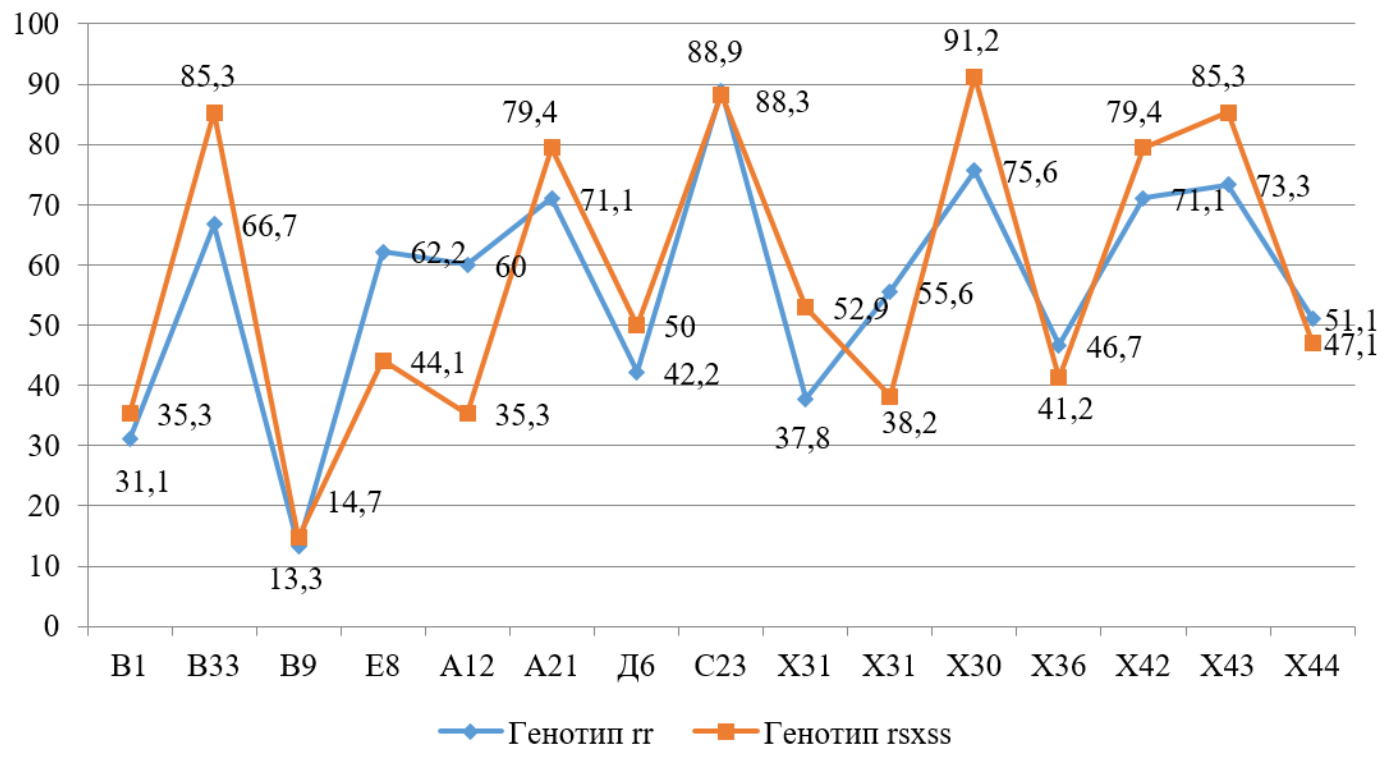

Рис. 2. Частота еритроцитарних антигенів у птиці лінії Д4 до ВСР 
У курей лінії П-37 нами відзначена вірогідна різниця в кількості птиці різних генетичних груп по локусам $\mathrm{B}_{18}$ i $\mathrm{E}_{8}$. Серед птиці цієї лінії генотипів rs i ss не встановлено особин, що мають локус $\mathrm{E}_{8}$, в той час як серед курей з генотипом гг вірогідно рідше виявляли птицю 3 локусом $\mathrm{B}_{18}$. У курей лінії Д-4 3 генотипом гг частота локусу $\mathrm{A}_{12}$ установлювали частіше, ніж у генотипів rs i ss. Що стосується частоти локусу В 33 , то спостерігали зворотну закономірність.
Повторні дослідження частоти антигенних факторів не виявлено закономірності повторення даних про наявність чи відсутність раніше названих чинників.

Ймовірно, немає зв'язку між наявністю визначених чинників еритроцитів у досліджуваних генотипів птиці по стійкості до інфікування ВСР або в нашому банку сироваток були відсутні такі, які виявляли б цей зв'язок.

Регресія пухлин вірогідно частіше відбувалася у птиці, що мала антигенний фактор $\mathrm{B}_{1}$ і при відсутності $\mathrm{B}_{33}$ (рис. 3).

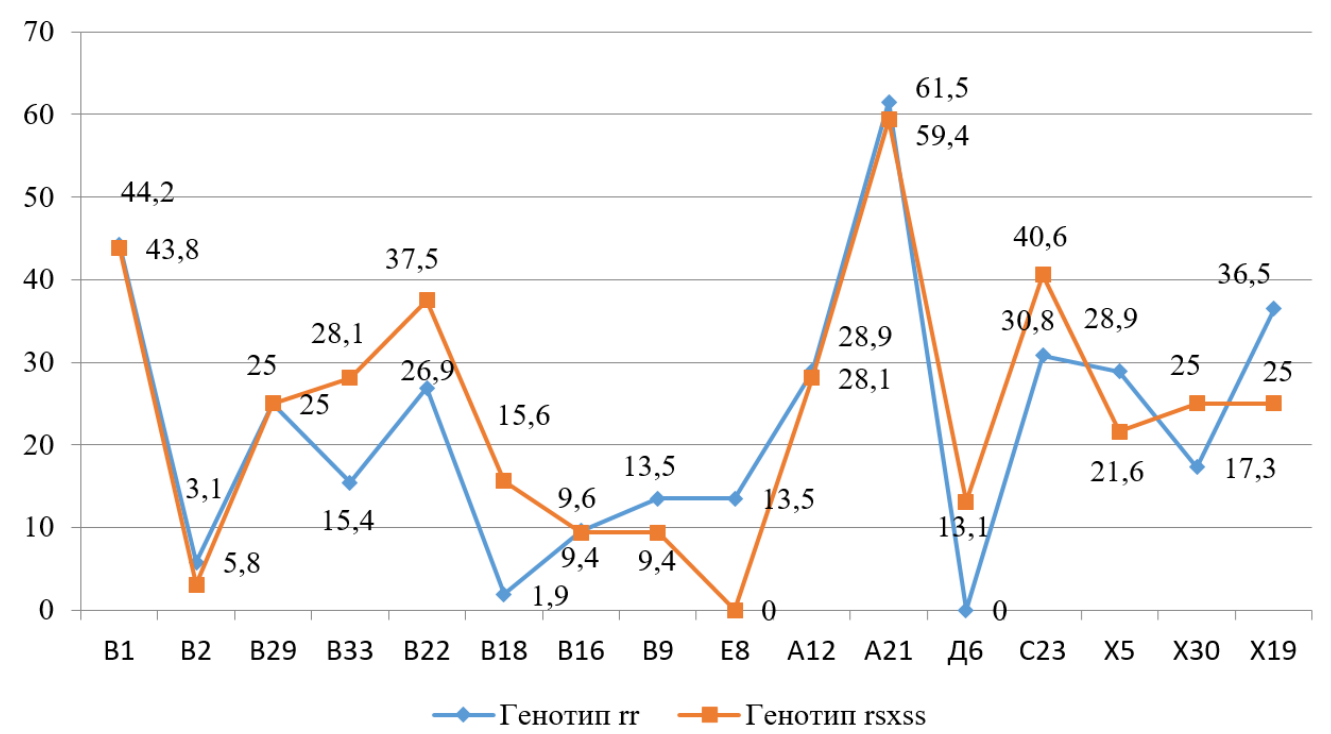

Рис. 3. Частота еритроцитарних антигенів у птиці лінії П37 до ВСР

Встановлена підвищена чутливість до непластичних захворювань курей носіїв антигенів $\mathrm{B}_{2}, \mathrm{~B}_{21}, \mathrm{~B}_{29}$, $\mathrm{X}_{50}$.

Payne L. N. спіавтори висловлювали припущення, що ген забарвлення оперення (i), якщо він $\epsilon$ в гомозиготній формі, являється інгібітором чутливості (Рayne \& Venugopal, 2000; Payne \& Nair, 2012). Для перевірки цієї гіпотези в дослідах використовувалися ембріони і курчата 3 різним забарвленням оперення: червоні, чорні, білі з жовтим відтінком, чисто білі. Оскільки у зародків важко розрізнити відтінки, всі білі з різними відтінками були віднесені до групи “білі”. 374 досліджених ембріонів червоних було 36 шт., Чорних 17, білих - 21, тобто співвідношення їх приблизно 2:1:1 або 3 частини “забарвлених" і 1 частина білих.

При зараженні ембріонів відповідно до схеми дігібридного схрещування передбачалося, що співвідношення стійких і чутливих зародків серед “забарвлених" і “незабарвлених" має бути однаковим (1:1), адже схрещували генотипи. Насправді вийшло, що серед “забарвлених" ембріонів стійких було більше, ніж чутливі (табл. 1).

\section{Таблиця 1}

Зв'язок гена забарвлення оперення з геном чутливості до онкарновірусів

\begin{tabular}{|c|c|c|c|c|c|c|}
\hline \multirow{3}{*}{$\begin{array}{c}\text { Забарвлення } \\
\text { ембріонів }\end{array}$} & \multirow{3}{*}{$\begin{array}{c}\text { Досліджено } \\
\text { ембріонів, штук }\end{array}$} & \multicolumn{3}{|c|}{ Співвідношення стійких до чутливих } & \multicolumn{2}{|c|}{$\begin{array}{c}\text { Критерії } \\
\text { Хi-квадрат }\end{array}$} \\
\hline & & \multirow{2}{*}{ фактичне } & \multicolumn{2}{|c|}{ теоретично очікуємо } & \multirow{2}{*}{$1-2$} & \multirow{2}{*}{$1-3$} \\
\hline & & & Без дії інгібітору & При дії інгібітору & & \\
\hline Червоні & 36 & $27-9$ & $18-18$ & $27-9$ & 8,6 & 0,00 \\
\hline Чорні & 17 & $13-4$ & $8-9$ & $17-0$ & 6,2 & 1,88 \\
\hline Білі & 21 & $15-6$ & $11-10$ & - & 3,0 & - \\
\hline
\end{tabular}

Фактично отримане розщеплення виявилося близьким до очікуваного, якщо допустити, що діє інгібітор. Але оскільки була проведена тільки одна серія дослідів, остаточний висновок зробити неможливо.
Можна лише зробити висновок, що ген забарвлення оперення все-таки якимось чином пов'язаний з геном чутливості. 


\section{Висновки}

Птиця фенотипу К-А має менше поширення серед птиці з забарвленим оперенням (полтавська глиниста, род-айленд). Леггорни всіх популяцій (за винятком канадського леггорну лінії В-7) відрізняються високою наявністю названого фенотипу. Характер успадкування ознаки клітинної сприйнятливості неоднаковий у генетично різних груп курей: у леггорнів він успадковується за типом неповного домінування, у полтавських глинистих також домінування відсутнє i, мабуть, воно пригнічується геном забарвлення оперення. Ген забарвлення оперення має певний зв'язок 3 геном чутливості до онкарновірусів.

Перспективи подальших досліджень. На підставі отриманих результатів досліджень в подальшому планується показники антигенів еритроцитів і генів забарвлення оперення птиці використовувати для визначення стійкості до непластичних захворювань.

\section{References}

Bhutia, L. D., \& Damodar, S. Y. (2017). Occurrence of lymphoid leukosis in poultry population of Mizoram. Indian Journal of Veterinary Pathology, 41(3), 228 231. doi: 10.5958/0973-970X.2017.00056.6.

Payne, L. N., \& Venugopal, K. (2000). Neoplastic diseases: Marek's disease, avian leukosis and reticuloendotheliosis. Revue scientifique et technique (International Office of Epizootics), 19(2), 544-564. doi: 10.20506/rst.19.2.1226.

Payne, L., \& Nair, V. (2012). The long view: 40 years of avian leukosis research. Avian Pathology, 41(1), 1119. doi: 10.1080/03079457.2011.646237.
Plachý, J., Reinišová, M., Kučerová, D. et al. (2017). Identification of New World Quails Susceptible to Infection with Avian Leukosis Virus Subgroup J. J. Virol, 91(3), e02002-16. doi: 10.1128/JVI.02002-16.

Plotnikov, V. A., Grebennikova, T. V., Dudnikova, E. K. et al. (2013). O rasprostranenii virusa lejkoza ptic v pticevodcheskih hozjajstvah Rossijskoj Federacii. Sel'skohozjajstvennaja biologija, 6, 36-42. URL: https:/cyberleninka.ru/article/n/o-rasprostraneniivirusa-leykoza-ptits-v-ptitsevodcheskih-hozyaystvahna-territorii-rossii/viewer (in Russian).

Rubin, H. (2011). The early history of tumor virology: Rous, RIF, and RAV. Proceedings of the National Academy of Sciences of the United States of America, 108(35), 14389-14396. doi: 10.1073/pnas.1108655108.

Soujanya, S, Lakshman, M., \& Madhuri, D. (2019). Occurrence of lymphoid leukosis in chicken. The Pharma Innovation Journal, 8(1), 159-162. URL: https://www.thepharmajournal.com/archives/2019/vol 8issue1/PartC/7-12-87-759.pdf.

Tsang, S. X., Switzer, W.M., Shanmugam, V. et al. (1999). Evidence of avian leukosis virus subgroup E and endogenous avian virus in measles and mumps vaccines derived from chicken cells: investigation of transmission to vaccine recipients. J Virol, 73(7), 5843-5851. URL: https://www.ncbi.nlm.nih.gov/pmc/ articles/PMC112645.

Vahrusheva, T. I. (2020). Osobennosti patomorfologicheskih projavlenij hronicheskogo mieloidnogo lejkoza u kur. Vestnik KrasGAU, 1(154), 62-75. doi: 10.36718/18194036-2020-1-62-75 (in Russian). 